\title{
Correction: Direct production of biodiesel from high-acid value Jatropha oil with solid acid catalyst derived from lignin
}

\author{
Fei-ling Pua ${ }^{1}$, Zhen Fang ${ }^{2 *}$, Sarani Zakaria ${ }^{1}$, Feng Guo $^{2}$ and Chin-hua Chia ${ }^{1}$
}

\section{Correction}

We found an important error in our published paper [1]. On page 7, Section: One-step conversion of Jatropha oil to biodiesel, line 3 , we wrote a reaction temperature of 120degreesC. The correct temperature should be 220 degreesC. The pressure was also omitted from the same reaction description and should be $7.1 \mathrm{MPa}$.

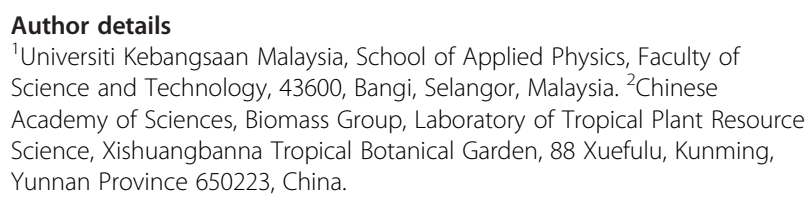

\section{Reference}

1. Fei-ling P, Zhen F, Sarani Z, Feng G, Chin-hua C: Direct production of biodiesel from high-acid value Jatropha oil with solid acid catalyst derived from lignin. Biotechnology for Biofuels 2011, 4:56.

\section{doi:10.1186/1754-6834-5-66}

Cite this article as: Pua et al:: Correction: Direct production of biodiesel from high-acid value Jatropha oil with solid acid catalyst derived from lignin. Biotechnology for Biofuels 2012 5:66.

\footnotetext{
* Correspondence: zhenFANG@xtbg.ac.cn

${ }^{2}$ Chinese Academy of Sciences, Biomass Group, Laboratory of Tropical Plant Resource Science, Xishuangbanna Tropical Botanical Garden, 88 Xuefulu, Kunming, Yunnan Province 650223, China

Full list of author information is available at the end of the article
}

\section{Submit your next manuscript to BioMed Central} and take full advantage of:

- Convenient online submission

- Thorough peer review

- No space constraints or color figure charges

- Immediate publication on acceptance

- Inclusion in PubMed, CAS, Scopus and Google Scholar

- Research which is freely available for redistribution

Submit your manuscript at www.biomedcentral.com/submit 